\title{
Double aortic arch: a cause of stridor to remember
}

\author{
Vera Baptista, ${ }^{1}$ Inês Azevedo, ${ }^{2}$ Gisela Rio, ${ }^{3}$ Carla Moreira ${ }^{1}$
}

'Department of Pediatrics, Hospital de Braga, Braga, Portugal

2Department of Pediatrics, Faculty of Medicine, Centro Hospitalar S João, Oporto, Portugal

${ }^{3}$ Department of Radiology, Hospital de Braga, Braga, Portugal

\section{Correspondence to}

Dr Vera Baptista,

verabaptista1@sapo.pt

Accepted 26 November 2015

\section{DESCRIPTION}

A previously healthy baby boy was admitted several times to the paediatric emergency department, from the age of 2 months, presenting respiratory distress, cough and wheezing. The episodes were managed as viral respiratory infections and inhaled bronchodilators, oral corticosteroids and chest physiotherapy were prescribed. At 6 months of age, during the third hospitalisation, a biphasic stridor was noted. The nasolaryngofibroscopy initially performed was unremarkable. At 7 months, a fiberoptic bronchoscopy showed a pulsatile tracheal compression, suggestive of a vascular ring. An MRI study showed a double aortic arch, confirming the clinical suspicion (figures 1 and 2).

Respiratory distress in children may or may not occur due to processes involving the respiratory tract. ${ }^{1}$ Many children are affected by recurrent lower respiratory tract infections and this is a frequent cause for urgent medical consultation. The challenge is to suspect and find the rare cases that might have an underlying disease. ${ }^{2}$ Stridor is a sign that suggests a significant obstruction of the large airways.

Vascular rings are rare congenital anomalies due to abnormal development of the aortic arch. In a

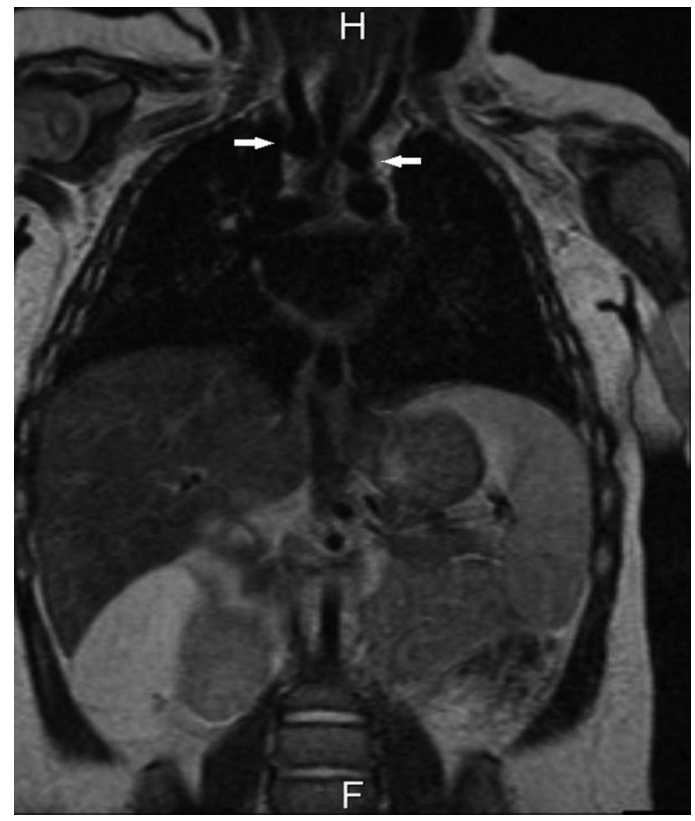

Figure 1 Thoracic MRI examination, coronal plane, showing two aortic branches (white arrows), on either side of the trachea, compressing and deforming the trachea.

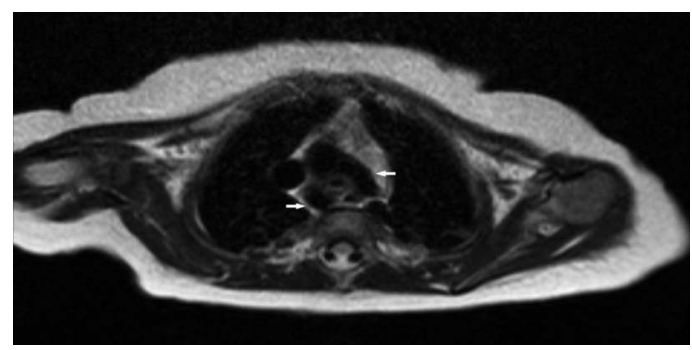

Figure 2 Thoracic MRI examination, axial plane, showing two aortic branches (white arrows), one anterior and the other posterior, to the trachea and oesophagus, encircling and compressing these structures.

double aortic arch, the ascending aorta bifurcates anteriorly to the trachea and oesophagus, completely encircling them. The arches then rejoin into a single descending posterior aorta. Vascular rings may cause a compression of the tracheobronchial tree and oesophagus, leading to respiratory infections, respiratory distress, stridor, wheezing, cough, dysphagia and feeding difficulties. The only definitive treatment is surgery. ${ }^{3}$

\section{Learning points}

Many children are affected by recurrent lower respiratory tract infections; it is a challenge to find those cases that might have underlying lung or extrapulmonary disease.

- The clinician must have a high degree of suspicion in order to diagnose a vascular ring, as it is a relatively uncommon cause of respiratory distress.

Competing interests None declared.

Patient consent Obtained.

Provenance and peer review Not commissioned; externally peer reviewed.

\section{REFERENCES}

1 Weiner DL. Causes of acute respiratory distress in children. http:// www.uptodate.com/contents/causes-of-acute-respiratory-distress-inchildren (accessed 1 Sep 2015).

2 Patria M, Esposito S. Recurrent lower respiratory tract infections in children: a practical approach to diagnosis. Paediatr Respir Rev 2013:14:53-60.

3 Juraszek AL, Fulton DR. Vascular rings. http://www.uptodate.com/ contents/vascular-rings (accessed 1 Sep 2015). 
Copyright 2015 BMJ Publishing Group. All rights reserved. For permission to reuse any of this content visit http://group.bmj.com/group/rights-licensing/permissions.

BMJ Case Report Fellows may re-use this article for personal use and teaching without any further permission.

Become a Fellow of BMJ Case Reports today and you can:

- Submit as many cases as you like

- Enjoy fast sympathetic peer review and rapid publication of accepted articles

- Access all the published articles

- Re-use any of the published material for personal use and teaching without further permission

For information on Institutional Fellowships contact consortiasales@bmjgroup.com

Visit casereports.bmj.com for more articles like this and to become a Fellow 